\title{
PENGARUH MODEL PEMBELAJARAN DISCOVERY LEARNING BERBASIS LKS TIPE WORD SQUARE TERHADAP KETERAMPILAN BERPIKIR KRITIS SISWA
}

\author{
Lala Laura Rahman', Adun Rusyana², Lia Yulisma ${ }^{3}$ \\ 1,2,3Program Studi Pendidikan Biologi, Universitas Galuh, Jl. R.E. Martadinata No. 150, Ciamis, Indonesia \\ Email: adunrusyana@gmail.com
}

\begin{abstract}
Learning often taking place rigidly and applied teacher centered results in passive students during learning. The fact has proven that student centered learning is needed to improve students 'higher order thinking skills, one of which is students' critical thinking skills. The purpose of this study is to investigate the effect of discovery learning model based on word square type of worksheet towards critical thinking skills of high school students with the sub- topic of environmental pollution. The research takes place in April 2020 involving the population of class X IPA MAN 2 Ciamis and 25 students of class X IPA 1 as a sample which is selected purposively. This study used a pre-experimental design method with the type of One Group Pretest-Posttest Design. The instrument used was critical thinking questions consisting of 20 multiple choice questions. The data obtained from the questions were processed statistically using the $Z$ test. The results shows that Zcount > Ztable with the value of 3.00> 2.33 means that the application of discovery learning learning model based on word square type worksheets has a great effect on critical thinking skills of high school students in learning the subtopic of environmental pollution. The high level of influence covers 0.76 .
\end{abstract}

Keywords: Critical Thingking, Discovery learning, LKS Word square

\begin{abstract}
ABSTRAK
Pembelajaran yang berlangsung secara kaku dan bersifat teacher centered mengakibatkan siswa menjadi tidak aktif selama pembelajaran. Padahal, untuk meningkatkan kemampuan berpikir tingkat tinggi siswa yang salah satunya adalah kemampuan berpikir kritis, diperlukan pembelajaran yang bersifat student centered. Tujuan penelitian ini adalah untuk mengetahui pengaruh model pembelajaran discovery learning berbasis LKS tipe word square terhadap keterampilan berpikir kritis siswa SMA pada submateri pencemaran lingkungan. Waktu penelitian berlangsung pada bulan april 2020. Populasi penelitian ini adalah siswa-siswi kelas X IPA MAN 2 Ciamis. Sampel yang digunakan melibatkan siswa kelas X IPA 1 sebanyak 25 orang yang dipilih menggunakan teknik purposive sampling. Penelitian ini menggunakan metode Pra-eksperimen design dengan jenis One Group Pretest-Posttest Design. Instrumen yang digunakan adalah soal berpikir kritis yang berjumlah 20 soal pilihan ganda. Data yang diperoleh dari soal diolah secara statistik dengan menggunakan uji Z. Hasil penelitian menunjukan bahwa Zhitung > Ztabel yaitu sebesar 3,00>2,33. Hasil temuan tersebut membuktikan bahwa penerapan model pembelajaran discovery learning berbasis LKS tipe word square berpengaruh terhadap keterampilan berpikir kritis siswa SMA pada submateri pencemaran lingkungan dengan tingkat pengaruh tinggi yaitu sebesar 0,76 .
\end{abstract}

Kata Kunci: Discovery learning, Keterampilan Berpikir Kritis, LKS word square

Cara sitasi: Rahman, L. L., Rusyana, A \& Yulisma, L. (2021). Pengaruh Model Pembelajaran Discovery learning Berbasis LKS Tipe Word square terhadap Keterampilan Berpikir Kritis Siswa. J-KIP (Jurnal Keguruan dan IImu Pendidikan), 2 (1), 33-38. 


\section{PENDAHULUAN}

Pendidikan sudah seharusnya berorientasi dalam membentuk kepribadian manusia termasuk moral. Moral berkaitan dengan akhlak, budi pekerti, dan ajaran kesusilaan (Baharudin, 2020). Pada poin budi pekerti termasuk salah satunya yaitu dalam membentuk manusia yang dapat berpikir kritis. Menurut Duron, et. al. (Mustajab, et. al. 2018) bahwa berpikir kritis dapat dikembangkan melalui pembelajaran. Melalui proses pembelajaran, mengakibatkan adanya perubahan tingkah laku positif terhadap individu serta membelajarkan dan mengubah pola pikir individu menjadi individu yang berpikir secara kritis.

Pembelajaran adalah suatu proses yang terjadi antara guru dengan siswa. Namun saat ini, pembelajaran seringkali berlangsung secara kaku dan bersifat teacher centered yang mengakibatkan siswa menjadi tidak aktif selama pembelajaran. Proses pembelajaran disekolah dengan banyaknya materi yang diajarkan seringkali membuat siswa sebagai objek pembelajaran justru tidak memahami makna dari materi yang diajarkan sehingga keterampilan berpikir kritis siswa menjadi rendah dan tidak terasah secara optimal. Keterampilan berpikir kritis sangat diperlukan karena dapat membantu pembelajar dalam mengelola pikiran untuk memperoleh cara belajar yang sesuai, mengetahui makna serta inti pokok pembelajaran (Rositawati, 2018).

Model pembelajaran discovery adalah suatu model pembelajaran yang dalam prosesnya mengutamakan proses berpikir secara kritis dan analisis untuk menemukan sendiri jawaban dari suatu permasalahan (Martaida, et al. 2018). Cahyo (2013) mengatakan bahwa model pembelajaran penemuan atau discovery learning adalah suatu model mengajar yang mengatur sedemikian rupa proses pembelajaran dengan cara tanpa memberitahu langsung konsep materi kepada siswa, melainkan ditemukan sendiri oleh siswa. Model discovery learning dapat meningkatkan keaktifan siswa, hal tersebut karena siswa dituntut untuk menemukan pengetahuannya sendiri sehingga dapat membantu siswa dalam melatih dan mengembangkan kemampuan berpikirnya.

LKS merupakan salah satu media yang biasa digunakan dalam proses pembelajaran. LKS seringkali digunakan untuk melatih pengetahuan dan keterampilan berpikir siswa. Namun di zaman yang sudah canggih ini siswa seringkali dengan mudah mengisi LKS yang diberikan dengan hanya memindahkan jawaban yang didapat dari internet atau buku ke dalam LKS tanpa ditelaah terlebih dahulu apakah jawaban yang mereka pilih itu memang benar atau tidak.

LKS word square merupakan lembar kerja yang didalamnya terdapat beberapa pertanyaan dengan jawaban yang sudah disediakan dalam kotak-kotak. Jawaban tersebut harus dicari oleh siswa sesuai dengan pertanyaan yang ditanyakan. Dinal (2016) mengungkapkan bahwa Lembar Kerja Siswa (LKS) Word square adalah suatu media pembelajaran yang didalamnya terdapat kotakkotak kata dan berisi kumpulan huruf. Huruf-huruf tersebut merupakan jawaban dari pertanyaan yang disajikan yang kemudian harus ditemukan sendiri oleh siswa. LKS word square dapat meningkatkan keaktifan selama proses pembelajaran dan melatih kemampuan siswa dalam berpikir secara teliti dan kritis, melatih ketepatan siswa dalam menjawab pertanyaan, serta penguat pemahaman siswa terhadap materi yang diajarkan. Sedangkan untuk kekurangannya yaitu dapat mematikan kreatifitas siswa (Purnama, 2015).

Ennis mengungkapkan bahwa berpikir kritis adalah cara berpikir yang kerap dikaitkan dengan berpikir secara rasional dan reflektif untuk membuat keputusan tentang apa yang dilakukan dan dipercayainya (Ridho, et. al. 2020). Berpikir kritis merupakan salah satu kemampuan berpikir dengan mengolah informasi yang diterima secara rasional, sistematis dan logis. Orang yang terbiasa berpikir tingkat tinggi akan dapat membedakan antara yang benar dan yang bohong, fakta dan opini, pengetahuan dan keterampilan (Kartikasari, et al. 2018).

Rumusan masalah dalam penelitian ini adalah adakah pengaruh model pembelajaran discovery learning berbasis LKS tipe word square terhadap keterampilan berpikir kritis siswa SMA pada submateri pencemaran lingkungan?. 


\section{METODE PENELITIAN}

Penelitian ini dilaksanakan pada bulan April 2020. Tempat penelitian dilaksanakan di MAN 2 Ciamis. Metode yang digunakan dalam penelitian ini adalah metode pra-eksperimen, yaitu metode eskperimen yang masih terdapat variabel luar yang ikut berpengaruh terhadap terbentuknya variabel dependen (Sugiyono, 2012). Dengan desain penelitian yang digunakan adalah "One Group PretestPosttest Design" yang divisualisasikan pada Tabel 1.

Tabel 1. Rancangan Eksperimen

\begin{tabular}{cccc}
\hline Kelas X & $\mathrm{O}_{1}$ & $\mathrm{X}$ & $\mathrm{O}_{2}$ \\
\hline \multicolumn{3}{c}{ Sumber: A \& Damaianti, (2011) }
\end{tabular}

Populasi dalam penelitian ini adalah seluruh siswa-siswi kelas X IPA MAN 2 Ciamis. Anggota populasi terdiri dari 5 kelas dengan jumlah 170 siswa. Sampel penelitian ini adalah kelas $X$ IPA 1 yang berjumlah 33 siswa, namun pada pelaksanaan pembelajaran dari 33 siswa hanya 25 siswa yang dapat mengikuti pembelajaran secara online. Pemilihan kelas eksperimen dilakukan dengan teknik simple purposive sampling. Pemilihan tersebut berdasarkan pertimbangan bahwa kelas tersebut memiliki kriteria kemampuan berpikir kritis rendah dan homogen.

Instrumen yang digunakan adalah berupa tes untuk mengukur keterampilan berpikir kritis siswa pada materi pencemaran lingkungan sebelum dan setelah diterapkan model pembelajaran. Tes tersebut berupa tes pilihan ganda yang berjumlah 20 soal yang mengacu pada indikator berpikir kritis yang digunakan dalam penelitian ini. Pengumpulan data dilakukan dengan:

1. Memberikan pretest kepada siswa mengenai materi pencemaran lingkungan secara online melalui media aplikasi whatsapp.

2. Memberikan posttest keterampilan berpikir kritis kepada siswa mengenai materi pencemaran lingkungan secara online melalui media aplikasi whatsapp Tahap Pengolahan/Analisis data:

Data kuantitatif dianalisis dengan menggunakan ukuran-ukuran statistik. Setelah melakukan penelitian, data yang diperoleh kemudian diuji sebagai prasyarat analisis yang dijabarkan sebagai berikut:

1. Uji Normalitas

2. Uji Hipotesis

Karena data berdistribusi normal maka langkah selanjutnya dilakukan uji hipotesis menggunakan uji Z (Nurgana, 1985).

a. Menghitung nilai $Z$

$$
Z=\frac{x / n-p}{\sqrt{p(\underline{1}-p)}}
$$

Keterangan: $\mathrm{x}=$ banyak data termasuk kategori hipotesa

$\mathrm{n}=$ banyak data $\mathrm{p}=$ proporsi pada hipotesa

proporsi yang digunakan dalam penelitian ini yaitu 50 , dengan kriteria tinggi.

b. Penentuan nilai $Z$ dari daftar

c. Pengujian Hipotesis

- Jika nilai $Z \leq-Z$ daftar maka hipotesis ditolak

- Jika nilai Z > - Z daftar maka hipotesis diterima

3. Uji Tingkat Pengaruh

Untuk mengetahui adakah pengaruh, dapat dihitung menggunakan N-Gain. Menurut Hake (2002) $\mathrm{N}$-gain dapat dihitung dengan menggunakan rumus sebagai berikut:

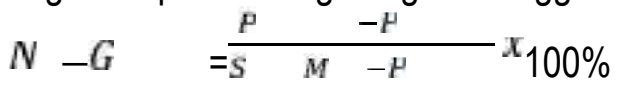

Dengan kriteria sebagaimana pada Tabel 2. 
Tabel 2. Kriteria N-Gain

\begin{tabular}{ll}
\hline Koefisien & \\
\hline Normalitas gain & Klasifikasi \\
$\mathrm{g}>0,7$ & Tinggi \\
$0,3 \leq \mathrm{g} \leq 0,7$ & Sedang \\
$\mathrm{g}<0,3$ & Rendah \\
\hline
\end{tabular}

Sumber: Hake (2002)

\section{HASIL DAN PEMBAHASAN}

Data penelitian diperoleh dari hasil nilai pretest dan posttest. Sedangkan data yang dianalisis adalah data gain. Adapun data yang diperoleh dari hasil penelitian disajikan pada Tabel 3.

Tabel 3. Hasil Perhitungan U ji Normalitas Data Gain

\begin{tabular}{llll}
\hline Sumber variasi & Tabel hitung & $\underline{(\mathrm{a}=1 \%)}$ & Keterangan \\
\hline Rata-rata Pretest & 34,60 & & \\
Rata-rata Posttest & 84,20 & & \\
Rata-rata N-gain & 0,76 & & Tinggi \\
X2 & 6,75 & 11,3 & Data berdistribusi normal \\
Z & 3,00 & 2,33 & Berperngaruh \\
\hline
\end{tabular}

Berdasarkan hasil analisis data yang telah dilakukan, maka dapat diketahui bahwa penerapan model pembelajaran discovery learning berbasis LKS tipe word square berpengaruh terhadap keterampilan berpikir kritis siswa SMA pada submateri pencemaran lingkungan. Hal ini didukung oleh pendapat yang dikemukakan oleh Martaida, et. al. (2018) bahwa model pembelajaran discovery learning merupakan pembelajaran yang menekankan pada proses berpikir secara kritis selama pembelajaran sehingga kemampuan berpikirnya dapat digunakan secara optimal. Hal tersebut dapat terjadi karena dengan menggunakan model pembelajaran discovery learning siswa dituntut untuk aktif dan menemukan sendiri jawaban dari suatu permasalahan sehingga kemampuan berpikir siswa dapat digunakan dengan baik.Selain itu, adanya penggunaan LKS word square membuat siswa tidak hanya sembarang mengisi jawaban, melainkan siswa mencari jawaban yang benar dan rasional sesuai dengan apa yang ditanyakan. LKS word square membuat siswa tidak sekedar mengingat atau menghapal saja, tetapi melatih proses berpikir siswa lagi dengan masuk akal sehingga memungkinkan terbentuknya berpikir kritis siswa.

Dari hasil penelitian diperoleh nilai rata-rata pretest 34,60 dan rata-rata posttest 84,20 . Dilihat dari rata-rata tersebut tentu menunjukan adanya peningkatan dengan menggunakan model pembelajaran discovery learning berbasis LKS tipe word square. Dari hasil penelitian dapat diketahui bahwa nilai $\mathrm{N}$-gain yang didapatkan sebesar 0,76 . Nilai tersebut menunjukan adanya peningkatan keterampilan berpikir kritis siswa yang termasuk dalam kategori tinggi. Hal tersebut dikarenakan siswa pernah menggunakan model pembelajaran seperti ini pada mata pelajaran lain sehingga siswa cukup siap dalam mengikuti pembelajaran. Selain itu, adanya penggunaan LKS word square membuat keaktifan masing-masing siswa selama diskusi. Hal ini sesuai dengan penelitian yang dilakukan oleh Dinal (2016) bahwa model pembelajaran yang divariasikan dengan LKS word square memiliki respon positif terhadap keaktifan dalam aktivitas belajar mengajar. Dengan adanya keaktifan siswa selama proses belajar, maka dapat memacu proses berpikir siswa sehingga dapat mengasah keterampilan berpikir kritis siswa.

Munculnya keterampilan berpikir kritis siswa dapat terbentuk karena melalui beberapa proses. Menurut Retnowati, et al. (2016) menyatakan proses berpikir kritis meliputi klarifikasi dasar, pendukung dasar, inferensi, klarifikasi lanjutan dan strategi dan cara-cara sehingga sampai pada tingkat keterampilan berpikir kritis. Pada tahap klarifikasi dasar, siswa berusaha memahami masalah yang ada, mampu mengemukakan pertanyaan dan jawabannya sendiri. Pada tahap pendukung dasar, siswa dapat memutuskan sumber yang relevan sehingga mampu membuat pengamatan 
sendiri dari hasil yang didapatkannya. Pada tahap inferensi, siswa mampu memutuskan kesimpulan yang logis. Pada tahap klarifikasi lanjutan, siswa dapat menentukan konteks definisi dengan tepat. Dan pada tahap strategi dan cara-cara, siswa melakukan interaksi dengan siswa lain untuk menentukan tindakan yang sesuai dan tepat sehingga dapat membuat alternatif solusi yang lain.

Namun dalam pembelajaran yang dilakukan secara online ini, ada beberapa faktor yang juga dapat mempengaruhi berpengaruh nya model pembelajaran discovery learning berbasis LKS tipe word square terhadap keterampilan berpikir kritis siswa yaitu tidak adanya pengawasan dari peneliti sehingga adanya kemungkinan siswa ketika mengerjakan pretest dan posttest melakukan open book, googling atau bahkan siswa saling bertanya dengan temannya, sehingga nilai siswa menjadi lebih tinggi. Selain itu, pemberian pretest dan posttest dalam waktu yang berbeda juga merupakan salah satu faktor yang dapat mempengaruhi tingkat berpengaruhnya model pembelajaran discovery learning berbasis LKS tipe word square terhadap keterampilan berpikir kritis siswa sehingga penelitian berjalan kurang efektif.

Melalui tahap-tahap tersebut siswa menjadi terampil karena proses berpikirnya dilatih dengan optimal dan runtut, sehingga siswa dapat sampai pada pemikiran kritis yang diharapkan. Selain itu, tahap-tahap tersebut juga berkaitan dengan model pembelajaran discovery learning berbasis LKS tipe word square, dimana siswa dituntut untuk mampu memahami dan mengidentifikasi masalah, mencoba untuk menemukan jawabannya sendiri sehingga siswa dapat menentukan kesimpulan yang tepat dan rasional setelah melalui proses pengumpulan data atau sumber yang relevan.

Dari kegiatan pembelajaran yang telah dilakukan dalam penelitian ini hasilnya cukup baik. Pelaksanaan pembelajaran dengan model discovey learning berbasis LKS tipe word sqaure dapat dimanfaatkan untuk menjadikan setiap siswa dalam kelompok menjadi aktif selama diskusi, dan dengan menggunakan LKS word square menjadikan siswa menjadi teliti dalam berpikir sehingga proses berpikir kritis siswa dapat terbentuk.

\section{KESIMPULAN}

Berdasarkan hasil penelitian dan analisis data yang telah dilakukan, maka dapat disimpulkan bahwa Zhitung > Ztabel yaitu sebesar 3,00 > 2,33, artinya penerapan model pembelajaran discovery learning berbasis LKS tipe word square berpengaruh terhadap keterampilan berpikir kritis siswa SMA pada submateri pencemaran lingkungan dengan tingkat pengaruh tinggi yaitu sebesar 0,76 .

\section{REKOMENDASI}

Penelitian ini memiliki kendala dalam waktu dan kondisi yang mengharuskan pembelajaran dilakukan secara online karena dilaksanakan pada saat pandemic covid-19 jadi perlu adanya perbaikan pada proses pembelajaran agar kendala tersebut dapat diminimalisir.

\section{UCAPAN TERIMAKASIH}

Terima kasih kepada kepala MAN 2 Ciamis yang telah mengizinkan penelitian ini dilaksanakan.

\section{DAFTAR PUSTAKA}

A. R, S., \& Damaianti, V.S. (2011). Metode Penelitian Pendidikan Bahasa. Bandung. PT Remaja Rosdakarya.

Baharudin. (2020). Nilai-Nilai Moral Masyarakat Sunda (Kajian Naskah Sewaka Darma Di Situs Kabuyutan Ciburuy Garut). J-KIP (Jurnal Keguruan dan IImu Pendidikan) , 1 (2), 41-46.

Cahyo, A.N. (2013). Panduan Aplikasi Teori-Teori Belajar Mengajar. Jogjakarta. DIVA Press. 
Dinal, J. (2016). Model Pembelajaran Partner Switch Yang Divariasikan Dengan Lks Word square Pada Materi Perkembangan Model Atom Di Kelas X SMA Negeri 2 Salang Kabupaten Simeuleu. Skripsi. Diterbitkan. Fakultas Tarbiyah dan Keguruan. Univeristas Islam Negeri Ar-Raniry: Darussalam, Banda Aceh.

Hake, R. R. (2002). Relationship of Individual Student Normalized Learning Gains in Mechanics with Gender, High-School Physics, and Pretest Scores on Mathematics and Spatial Visualization. Tersedia: http://www.physics.indiana.edu/ hake. [2 Februari 2020]

Kartikasari, D., Medriati, R. \& Purwanto, A. (2018). Penerapan Discovery learning Model dengan Pendekatan Saintifik untuk Meningkatkan Kemampuan Berpikir Kritis Siswa pada Konsep Kalor dan Perpindahan Kalor. Jurnal Kumparan Fisika, 1(2),1-7.

Martaida, T., Bukit, N. \& Ginting, E. M. (2018). Efek Model Pembelajaran Discovery Terhadap Kemampuan Berpikir Kritis Dan Hasil Belajar Kognitif Siswa SMP. Jurnal Pendidikan Fisika, 7(2), 118-123.

Mustajab, W., Senen, S.H. \& Waspada, I. (2018). Analisis Kemampuan Berpikir Kritis Siswa SMA pada Materi Koperasi. Oikos:Jurnal Kajian Pendidikan Ekonomi dan Ilmu Ekonomi,11(1), 5256.

Nurgana, E. (1985). Statistika untuk Penelitian. Bandung: C.V.

Permadi. O, A. (2018). Pengembangan Lembar Kerja Siswa Word square Program Remedial Untuk Meningkatkan Penguasaan Materi Ditinjau Dari Minat Belajar Fisika Dan Kemampuan Berpikir Kritis SMA. Skripsi. Diterbitkan. Fakultas Matematika dan IImu Pengetahuan Alam. Univeristas Negeri Yogyakarta: Yogyakarta.

Purnama, M. B. (2015). Pengaruh Pembelajaran Make A Match dengan Media LKS Word square terhadap Hasil Belajar Sejarah Siswa Kelas XI IPS SMA Negeri 1 Kramat Tahun Ajaran 2014/2015. Skripsi. Diterbitkan. Fakultas IImu Sosial. Semarang: Universitas Negeri Semarang.

Retnowati, D., Sujadi, I. \& Subanti, S. (2016). Proses Berpikir Kritis Siswa Kelas XI SMK Citra Medika Sragen dalam Pemecahan Masalah Matematika. Jurnal Elektronik Pembelajaran Matematika, 4(1), 105-116.

Ridho, S., Ruwiyatun, Subali, B. \& Marwoto, P. (2020). Analisis Kemampuan Berpikir Kritis Siswa Pokok Bahasan Klasifikasi Materi dan Perubahannya. Jurnal Penelitian Pendidikan IPA, 6(1), 10-15.

Rositawati, D. N. (2018). Kajian Berpikir Kritis Pada Metode Inkuiri. Prosiding SNFA (Seminar Nasional Fisika dan Aplikasinya).

Sugiyono. (2012). Metode Penelitian Kuantitatif, Kualitatif, dan R \& D. Bandung: ALFABETA. 